\title{
"Women Are Truly Wonderful in their Ingenuity": Radical Housewives and Consumer Protest During the Cold War Era
}

\author{
Brian Thorn, Trent University
}

Following the end of the Second World War, the Canadian federal government, through the Consumer Branch of the Wartime Prices and Trace Board (WPTB), the body charged with monitoring and controlling prices of goods on the home front, proceeded with the removal of price controls on staple foods such as milk, butter, and meat, which had allowed working families to afford the goods they needed to survive during war time.. This "decontrol" of prices led to significant increases in the prices of basic foodstuffs, and in rent, both significant hardships for poor and working-class families. ${ }^{1}$ Left-wing women in the Communist Party of Canada (CPC or CP) and the Co-operative Commonwealth Federation (CCF) did not stand by while this went on. ${ }^{2}$

Writing in the party's newspaper, the CCF News, prominent social democrat Mildred MacLeod commented on the issue of household consumption. MacLeod offered a rejoinder to federal finance minister Donald Gordon's remarks that Canadian housewives could be a "secret weapon against inflation." She suggested that poor and working-class women met "the ever-dwindling purchasing power of Hubby's pay cheque by doing without clothes for themselves," as well as without pleasures like a film or haircut. Radical women and men should be demanding action through protests, MacLeod argued. High prices were "lowering the standards of education, adding to delinquency," and "causing further deterioration of home life." 3 MacLeod claimed that foodstuffs like bread, milk, and eggs were staples of specifically working-class family diets. She argued that working-class women controlled the cooking and diet for their families; in this way, MacLeod established women as key players in debates over the price of goods.

MacLeod asserted that a link existed between high prices and the antiwar movement: wage reductions and high prices were occurring in "a country wealthy enough to spend billions on defence ... we would like some butter, never mind about the guns." She suggested that working women and wives "insist on having enough purchasing power to insure us against malnutrition, against TB, against hopelessness and despair." "Yes, girls," she exclaimed, "we can be a 'weapon against inflation,' just watch the hornets' nest we can stir up." "Women," MacLeod concluded, "are truly wonderful in their ingenuity."4 
Left-wing women found a place for their ingenuity as members of organizations like the Communist-founded Housewives' Consumers Association (HCA), established in 1947, which initially attracted both CP and CCF women. ${ }^{5}$ HCA women argued that they were "radical housewives": they offered a challenge to unscrupulous capitalists who cared only for profits and not for the poverty in Canadian cities and towns. Like Mildred MacLeod, HCA members suggested that capitalists were causing malnutrition, hopelessness, and disease among working-class children. ${ }^{6}$

This article discusses the activities and ideologies of CP and CCF women in consumer protests during the period from 1945 to 1960, using women's activism in the British Columbia (BC) Housewives' Consumers Association as a case study. ${ }^{7}$ This paper presents two major arguments. First, it argues that left women used the issue of high prices as a form of "strategic essentialism": the use of a narrow definition of a woman's role in a specific context in order to extract concessions from the dominant system. ${ }^{8}$ Left women suggested that their role as mothers to children represented their primary function in life. This was "essentialist" in that it put forward what many have seen as a conservative view of a woman's purpose in life. Left women's rhetoric upheld the sexual division of labour: women's primary labour involved reproduction and the raising of children, and domestic work. Working-class men, in contrast, lived in the public world of the factory floor. Left women used this definition of a woman's role to present a radical social agenda. ${ }^{9}$ CP and CCF women asserted that their experiences as workers and mothers provided them with special insights surrounding action against the high prices of staple foods. Many, perhaps most, women of the 1940s and 1950s were wives and mothers: they were thus concerned about feeding their families. High prices made this task more difficult. Non-political women, however, were not necessarily interested in left-wing ideology; to that end, radical women used the issue of consumption strategically to appeal to diverse groups of women.

Second, the paper argues that CP and CCF women regarded motherhood as partial justification for their political activism outside of the home. They did not see motherhood and the domestic sphere as negative or inferior to the public sphere. Left women used their "female consciousness" 10 to organize in their communities against high prices of goods, and in favour of a just and fair standard of living for working families. ${ }^{11}$ In doing this, left women established a network of community activism against high prices that drew on women's experiences as wives and mothers. This use of maternalism was positive for the growth of women's activism in the late-1940s and 1950s, especially given the constraints that the anti-communist atmosphere of the Cold War introduced for people of the left. ${ }^{12}$ Certainly, not all left women used maternalism as an organizing strategy, but the fact that there was a great deal of maternalist language in 
the radical press, and in the discourse of prominent left women, suggests that maternalism was a key idea for many radical women during this period. Left women's activism was thus two-sided: it was strategic in that it used an ideology that many subscribed to - women as "natural" mothers and wives - but also it dovetailed with ideas that left women sincerely argued for.

\section{Maternalism and Consumer Protest}

The ideology of "maternalism" provided a basis for women's consumer protests. In this context, "maternalism" consists of three specific elements. First, maternalist thinkers from the 1940s and 1950s held that a uniquely feminine value system, based on care and nurturance, existed. Second, they suggested that a common capacity for motherhood united women: women shared a collective responsibility for protecting all of the world's children in times of economic scarcity. Finally, CP and CCF women asserted that their work, experience, and socialization as mothers made them uniquely able to lead certain kinds of reform campaigns. Many people of both genders, and various political orientations, subscribed to maternalist views because of long-held ideas that women were innately suited to being mothers, wives, and nurturers. Historically, maternalism represents a flexible and fluid concept that has been used to justify a wide variety of political and social agendas, from the far right to the far left. ${ }^{13}$

There is some controversy among feminist and leftist scholars over whether or not maternalism has been a useful strategy for movements of social protest. Some, like Dana Frank, have suggested that working-class and union women have used consumer practices to challenge capitalism, attacking sexism and capitalism at the point of consumption. ${ }^{14}$ In the Canadian context, Tarah Brookfield has argued that women from feminism's "second wave" drew on the idea of the home and family as a site of radicalism and protest, not a place of domesticity and retreat. Maternalist ideology, then, was a key part of women's activism in both the "Old" and "New" Lefts in Canada. ${ }^{15}$ Certainly, women's consumer protests had a long history: numerous women's groups over the course of the twentieth century had offered critiques of capitalism and consumption. ${ }^{16}$ $\mathrm{CP}$ and CCF women were part of a continuum of women's activism that extended from the Progressive Era of the early-1900s to the 1930 s. ${ }^{17}$ There was also considerable activism on the part of women during the late-1940s and 1950 s, sometimes seen as a period of conservatism and retreat. ${ }^{18}$

Conversely, other scholars have suggested that proponents of maternalism ceded too much ground to foes of women's liberation. ${ }^{19}$ Yet, the use of maternalism as a form of "strategic essentialism" brought people into the orbit of radical protest who otherwise would not have joined a leftist group. This suggests that maternalism should not be ignored as an avenue for radical protest, 
even today. This paper joins with other scholars who have portrayed women consumers as active agents of history and those who have seen consumption as a site of struggle. Kathleen Brown and Peter Campbell argue that women have supported leftist politics from the perspective of affirming family life against the influence of soul-destroying capitalism. Many left women did not argue that Marxism was a superior economic theory. Rather, they used left politics to argue that it would support and maintain working-class families - materially and spiritually - by transforming social relations from competitive to co-operative. ${ }^{20}$ As Temma Kaplan has argued, women's activism - of the left and the right - is often connected to a "female consciousness," that is, the notion that women organize to defend the family and to fight against anything that women believe will interfere with their ability to preserve life as they know it. ${ }^{21}$ Therefore, left women fought to break down barriers between the workplace and the home and the "public" and "private" spheres. ${ }^{22}$

Like Mercedes Steedman, this paper sees the "embeddedness" of women's networks in specific neighbourhoods and communities - in Vancouver and other locales in British Columbia - as being key to women's radical protest. $^{23}$ The paper differs from Joan Sangster and Magda Fahrni's work in its focus on the Cold War era and the 1950s and in its closer focus on maternalism as an overall, potentially positive, strategy for the left. I connect left women's use of maternalist ideology during the 1940s and 1950s to earlier, and subsequent, groups of left women who used a similar perspective. Unlike Julie Guard and Steedman, I focus not on perceptions of women's activity by the RCMP and male outsiders, but on the ideological background that fostered grassroots women's activism.

\section{Men and CP Women's Activism}

The CP's male leadership had an ambiguous perspective on women's activism. A statement written around 1948-49 offers detail surrounding women's roles in the party. In a manuscript entitled "Woman," a CP member argued that the party could best forward their objectives by working with CCF women as part of consumers' organizations, especially in the fight for lower prices. The statement encouraged leftists to fight for social services and the defence of women and children. Challenging the conventional Cold War portrayal of communists and socialists as being enemies of the family and home, the manuscript commented that the Labor Progressive Party (LPP) ${ }^{24}$ was the "defender of the home, the family, and the Independence of Canada." The writer noted that, "monopoly capitalism and its political henchmen, Liberals and Tories, are the destroyers of the family, the home, the rights of women, and welfare of children." Political and economic elites were "selling out our country to Yankee imperialism," 
reflecting the sense of Canadian nationalism and anti-imperialism that CP members sometimes invoked. ${ }^{25}$ The report commented on the different situations facing Communist women across Canada. The author asserted that the party should support female figures like Peggy Chunn, Effie Jones, and Helen Anderson, whom it wanted to present as potential public office holders. ${ }^{26}$ Women were still a small minority in the party, but the CP wished to present itself as "modern" and progressive on women's issues. ${ }^{27}$

Here, the CP hierarchy paid lip service to supporting women's activities. A 1948 issue of the party newspaper, the Pacific Tribune, printed a Draft Resolution of the National Executive of the LPP that also endorsed women's activity. The resolution noted that 1945-48 had seen "the activities of the women in their fight against monopoly prices and profiteering, the rising cost of living, and for the defence of the family." 28 According to this statement, the LPP needed to devote far more attention to the problems and struggles of women in the party and in society. In a similar vein, a bulletin from LPP National Leader Tim Buck implied that support for women's initiatives was an important priority. Buck expressed enthusiasm for the Housewives' campaign for a million signatures on a petition to reduce prices: "our party must do all in its power to help." Communists needed to offer their utmost support for a "mass delegation to the government" on the part of the HCA as well as for the establishment of a national Housewives' organization. ${ }^{29}$

Tim Buck later criticized "the Abbott plan," an attempt by federal Finance Minister Douglas Abbott and Prime Minister Mackenzie King to reduce Canadian imports of manufactured goods and food from the U.S. He used this as evidence that the Federal Liberals were mounting an attack on poor and working people. Buck argued that the plan was designed to effect a drastic reduction of Canadian consumption to make the country more dependent on the U.S. The Abbott plan was set up to "wipe out sovereignty" by giving the U.S. government a "direct voice in deciding the direction and level of Canada's economic development." Buck also advocated for closer relations between Canada and the Soviet Union. In support of the HCA program, he argued for "the reintroduction of price controls, government subsidies for low rental housing, an increase in Mothers' Allowances, and the abolishment of the $8 \%$ sales tax." 30

Publicly then, CP men expressed support for the fight against high prices. In fact, women's issues were a lower priority for the CP leadership than concerns surrounding unions and electoral politics. Women, associated in many people's minds with the home and family, were of secondary importance to men in the CP. The statements listed above serve to highlight the, more numerous, statements by male CP members that emphasized women's subordination in the movement. ${ }^{31}$ 


\section{Communist Women's Activism as "Radical Housewives"}

Despite lacking support from the party hierarchy, CP women played a crucial role in grassroots activism, thus turning the realm of the home and family into a site of struggle. Using maternalist arguments led women to adopt positions that diverged from those of their male comrades. In keeping with this, members of the Housewives' organizations supported many different causes. An unsigned article from the Pacific Tribune in June of 1946, entitled "Women Organize to Halt Raids on Family Budget," demonstrates some of their concerns. A group of Vancouver women had met, in Pender Auditorium, to protest against the removal of the milk subsidy. Adopting the name "Housewives United," - this group became part of the HCA in 1947 - the group's objective was to rally the support of all women who were concerned about "preventing further inflation" and to bring "pressure upon the government, protesting the lifting of price controls." 32 Since the original housewives' organization had dissolved before World War II, this new group represented a bridge between the Housewives League of the late-1930s and the new organization that came into existence in 1947. CP women wanted to bring to the public's attention the economic problems that beset housewives trying to make ends meet in the face of rising prices and food shortages. CP supporter Doris Hartley, a member of Housewives United, stated that, "the increased cost of milk will be more sharply felt by families with low incomes ... this means a lower standard of health for our children." 33

Communist women in $\mathrm{BC}$ challenged capitalism through consumer boycotts. In 1946, Vancouver CP women undertook a boycott of meat products. Instead of "meat tokens," Vancouver housewives handed their local butcher coupons that read "I bought no meat today." 34 This was part of Housewives United's campaign against high prices. CP women in housewives' organizations also fought against large department stores like Woodward's and Hudson's Bay, again using the consumer boycott as a tactic. Organized labour in Vancouver, through their representatives in the Vancouver District Labour Council (VDLC), endorsed this activism. The International Woodworkers of America's (IWA) District Council of Federated Women's Auxiliaries offered cooperation in the campaign. Mona Morgan was an important member of the HCA and had strong connections to the IWA as well as to the Labour Council. ${ }^{35}$ An article advertising the boycott commented that, "publicity will be given to the campaign through 'Five Minutes with Mona,", the popular IWA radio broadcast directed to women conducted by Morgan every weekday morning. ${ }^{36}$

Despite their small numbers, CP women put together effective consumer boycotts. Their efforts, if not successful in changing state policy, did introduce radical ideas surrounding consumption into mainstream thought. In this sense, the boycott was effective as a political strategy. Left women offered 
grassroots, locally based solutions to problems stemming from poverty and want. Delegates from the Women's Auxiliary of the IWA, Housewives' United, and the Vancouver Consumers' Council of the LPP demonstrated against the increase in milk prices. The protesters marched to the offices of the $\mathrm{BC}$ milk controller, E.C. Carr, demanding that the provincial Government pay producers a two-cent per quart subsidy to hold down prices. Premier John Hart refused to assume the cost of the milk subsidy since the federal government had withdrawn it. The Housewives responded that milk was an essential product and blamed both the federal and provincial governments for reducing wages. "Mothers know that increases in the cost of their children's food and clothing during the past year have already exceeded their family allowances," concluded the Pacific Tribune. ${ }^{37}$

The HCA's program was wide ranging: the organization dealt with a number of issues relevant to working mothers' lives. A letter addressed to Prime Minister Mackenzie King, signed by Rae Lucock, previously a school board trustee and CCF Member of the Legislative Assembly (MLA) as well as the President of the Toronto branch of the HCA, noted that the women supported curbing profiteering by imposing taxes on excess profits and corporations. HCA supporters lobbied the federal government to provide adequate pensions and social security measures - particularly affordable housing - for older citizens. Lucock asserted that the organization also supported youth concerns, arguing that higher education should be made affordable for students. ${ }^{38}$

As part of a campaign against youth poverty, the HCA favoured hot lunch programs for students as well as a government takeover of all social services, notably mothers' and widows' pensions, in order to assure "care for all." As socialists, the organization's members pushed for the establishment of public laundry depots, home cleaning services, and hot food centers. ${ }^{39}$ As mothers, HCA women fought to preserve life for their families and children. The HCA program reflected the political program of the CCF and, especially, the CP. Left women fought to make the Canadian state more "feminine," hoping to inaugurate the "pro-social" aspects of government policy in providing services for its citizens. ${ }^{40}$ Through publicizing the presence of poverty and unemployment, CPled groups in Canada gave the lie to the capitalist state's assertion that it was providing for all, an argument with which many people in Canada sympathized.

The high price of staple foods was a particularly important issue for CP women in British Columbia's interior. Mrs. J. Blakey, president of the Prince Rupert LPP club, commenting on an increase in milk prices, stated that "it was already hard enough for mothers to see their children got fresh milk, now it will be impossible for many." 41 Ottawa also legislated an increase in the price of canned and powdered milk. Left women's focus on milk, particularly its status as a life-giving product for children became part of their efforts to improve the quality of children's lives against the uncaring attitudes of conservative male 
bureaucrats in government and business. Housewives used milk products extensively in Prince Rupert and in logging, fishing, and mining camps. Food and supplies were also harder to obtain in isolated regions of the province. Clearly, some rural women possessed a maternalist sensibility. Recent scholarship has shown that Canadian farm and rural women played a significant role in women's, feminist, and leftist, activism. ${ }^{42}$ The particular "place" that these women hailed from influenced their views. ${ }^{43}$ The resource-based economy of BC, with its poverty, isolation, and male-dominated industries in the timber and mining sectors, led to economic issues taking a prime place of importance in the thoughts of BC's left women.

CP women on Vancouver Island also saw high milk prices as an important concern. The IWA Women's Auxiliary in Nanaimo put forward a request that the provincial Government restore the former milk price and provide farmers with a subsidy to offset their losses. Prominent CP member Effie Jones toured Vancouver Island to address a series of protest meetings dealing with the increase in the price of milk. Jones went to Cumberland, Courtenay, Port

Alberni, Cowichan, Nanaimo, and Ladysmith to speak to the wives of miners, loggers, and fishers. In one of her speeches, she demanded that a portion of the large revenue derived by the Hart government from liquor profits go toward paying "the cost of a subsidy to restore the September price of milk." Jones offered a commentary on provincial elites' indifference toward working-class families and their needs. In mentioning liquor profits, she hearkened back to maternal feminists' dislike of alcohol, although giving this argument an economic, rather than a moral, spin. ${ }^{44}$ Jones's comment implied the presence of a female consciousness, much as with previous generations of women activists. Women like Effie Jones fought for the necessities of life for children and families, at the community level, against the depredations of "free market" capitalism.

As part of the Vancouver Island protest against high milk prices, two thousand people in Nanaimo signed a petition in favour of restoring the milk subsidy. A broad-based committee, consisting of United Mine Workers of America (UMWA) and IWA Auxiliaries, the Women's Labor League (WLL), the Local Council of Women (LCW), the CCF, and the LPP, sponsored the petition. ${ }^{45}$ An article in November of 1946 noted that Courtenay women had demanded that Premier John Hart reinstitute the milk subsidy. Similarly, a conference of Island women, consisting of the wives of union members, urged Hart to "establish a democratic board of enquiry to investigate the enormous spread between what the producer receives for milk and the price the consumer receives."46

The price of children's clothing, emerging in the context of post-war scarcity, was an important point of contention for left women. The North Vancouver branch of Housewives United held a meeting on Monday, 2 
December 1946 to formulate a plan regarding the shortage of children's underwear and wool. ${ }^{47}$ In early 1947, action by the Women's Commission of the LPP, supported by the IWA Women's Auxiliaries, occasioned an article where Mona Morgan urged consumers "not to buy any but the most essential commodities." The LPP Women's Commission, "declaring that only organized buyer resistance can call a halt to the reckless drive to inflation and crisis," called for a protest rally in Lower Pender Auditorium on Thursday, 8 February 1947.48

In this way, left women fought to improve material conditions for working families, emphasizing women's status as mothers. The fight for access to affordable housing became part of the CP's strategy to fight poverty. This was an especially trenchant issue in the immediate post-World War II period given the large number of returning soldiers who needed homes. CP women were particularly concerned with the problem of rising rents in Vancouver. The LPP Women's Commission conducted a survey on rent controls, which revealed that increased income tax made it necessary for both husbands and wives to work. The Commission recommended that supporters of their housing platform trade unions, housewives, pensioners and other leftist organizations - send telegrams and resolutions of protest to governments. ${ }^{49}$ These examples suggest that, in spite of their relatively small numbers, CP women were practical fighters for social change, able to push for piecemeal reforms like better housing; at the same time, they ultimately desired more sweeping changes to capitalist society. In this sense, Irving Abella's argument that Communists were not "pie in the sky" dreamers, but instead pragmatic activists who helped to institute everyday reforms, rings true. ${ }^{50}$ In their focus on issues of importance to women and families, left women sought to make the private sphere a site of resistance to the dominant system. They also used their words and campaigns strategically to appeal to a wide group of Canadians, particularly women as mothers.

Hence, issues of production and consumption came out in CP women's discourse in important ways. In a comment dealing with the price of butter, Mona Morgan offered a critique of capitalism's abuse of mothers, housewives, and workers: "women recognize that the health of the nation is their particular responsibility and they know that with present high levels, health cannot be maintained but will grow worse and worse." Workers and housewives, she argued, knew that higher costs, low wages, and excessive profits all led to depression. ${ }^{51}$ Morgan called for price and rent controls, and higher wages so that working people's buying power would be maintained and another depression forestalled. CP members recognized that workers and wives were both producers and consumers of goods and services. Mona Morgan drew on a radical version of 19th-century "labourist" ideology. This view emphasized the differences between "producers," notably craft and industrial workers, and "parasites" like businessmen, immigrants, and women. Morgan's perspective on labourism, how- 
ever, was more radical. In her view, bosses were parasites while women and workers were producers. 52

In the American CP, similar debates emerged surrounding women's work. In 1941, member Mary Inman attempted to deal with the nature of domestic work in a book entitled In Woman's Defense. She argued that women, by undertaking domestic labour and bearing and raising children, participated in the process of social production by creating the labour power of present and future generations of workers. This viewpoint contrasted with other Marxist and labourist writing on this subject, some of which denigrated women's labour, stating that it was not productive. Women, so this argument went, were parasites who depended on their husbands' wages. Like Mona Morgan, Inman presented women's household labour as productive and valuable. Under socialism, Inman argued that women would be free from domestic labour, since a socialist society would have round-the-clock nurseries, and centralized laundry and cooking facilities. Many, though not all, men in the American CP rejected Inman's view that the party should accept the sexual division of labour and work to organize housewives in the home as workers. Instead, as in Canada, many in the American CP portrayed household labour as less valuable than factory work and argued that the road to women's equality lay in bringing women out of the home so that they could take their place as "real" workers on shop floors. But this was not the whole story. As Kate Weigand argues, Inman’s focus on women's household labour, as well as her support for a cross-class movement to push for women's rights, became part of the American CP's campaign around gender issues during the late-1940s and 1950s. ${ }^{53}$ Inman's writings resulted in increased women's activism in the American CP.

Canadian CP women were involved in these debates. In particular, Effie Jones praised the value of domestic labour. In early 1948, Jones ran for the Mayoralty in Vancouver for a second time. The Civic Reform Association (CRA), a Communist-led group, endorsed Jones's candidacy. Consumption became part of the discourse of this campaign: the CP argued that Vancouver's consumers could not keep up with the increasing cost of living. The party opposed any increase in the price of electricity, transportation, and gasoline. A Communist writer argued that, "women are more price-conscious than men." The author addressed female readers in the following fashion: "if hubby doesn't realize why you get so hot and bothered over the grocery bill, just make him tag along on a shopping day so he can see for himself how far five dollars will go." 54 The CP presented a critique of male insensitivity toward women's efforts at dealing with the family budget; working-class mothers had to stretch a dollar as far as possible in order to feed the family, even if fathers did not know how hard this was. 
Effie Jones offered some remarks on this issue, noting that, "it's the women who have to stretch the pay or pension cheque across the widening gap between minimum requirements and inflated prices." Women "have to cope daily with all the irritations and difficulties arising from crowded living conditions. They are the first to sacrifice their own health for their children because medical expenses come so high." Jones offered a tribute to working women's sacrifice for the good of the family. The "old-line party politicians" - Conservatives and Liberals - came under particular scrutiny for betraying the promise of the postwar dream. Women too had fought during World War II to "realize the promise of a better world," and to create a society that was free from fascism, discrimination, and poverty. Jones offered a pro-woman argument in the face of government callousness: "every Coalition politician and federal member will find to his sorrow that the female of the species can be far more deadly when fighting for the future of the young." 55 In presenting a criticism of capitalist attitudes toward consumption - and using what Temma Kaplan has termed "female consciousness" - Jones used maternalism to challenge the dominant system. ${ }^{56}$ We might actually see CP women's activism as "conservative" in a sense. They fought to maintain the integrity of their communities, homes, and families in the face of the capitalist state's attempt to reorder their lives through policies like the decontrol of prices. This was a perspective that other, more conservative or non-political people - women as well as men - supported. Some women in the CP and CCF not only took different positions from men in their parties but also made issues like high prices important to the general public. Maternalist arguments, then, led to an increase in left women's activism.

Elsewhere, Communist women emphasized other "pocket book" issues that were important to women as mothers, a key part of left women's strategy to appeal to diverse groups of Canadians. A CP writer noted in 1947 that the Vancouver HCA was "considering what action it can take to organize the protest against the BC Electric mooted increase in fares." The increase would hit working people every time they wished to go shopping downtown. In a similar vein, members of the Vancouver HCA organized a "bread brigade" due to price increases caused by a federal government decontrol order. CP women dealt with this issue by baking their own bread. As a Communist woman writer noted, "it was still cheaper to bake our own bread, despite the 90 percent rise in the price of flour." Some of the slogans that the Housewives used included "don't buy it, bake it" and "save dough, make dough." 57

The Communist-led Congress of Canadian Women (CCW) also supported keeping food prices low. ${ }^{58}$ In 1950 , a CP writer noted that the CCW planned to put a delegation together to meet with Vancouver City Council. This delegation asked the federal government to put a ceiling on the price of foods, clothing, and other items necessary to working-class family life. The CCW urged 
all concerned with the issue, particularly women, to attend. Supporter Mavis Wall encouraged readers to "fight the high cost of living. Demand that our government take action to bring down prices on meat." She exhorted readers to become active in community groups: people should talk to their neighbours, and urge them to join left organizations. ${ }^{59} \mathrm{CP}$ women used arguments around consumption in order to recruit new party members.

During the 1950s, the issue of high prices became less of a concern for Communist women, possibly for reasons related to the relative affluence of the decade. The stark decline of the CP's numbers and power, because of Cold War repression and the post-1956 revelations of Stalin's crimes, was likely a contributing factor as well. One of the final declarations of CP women on this issue came in August of 1950. The BC Council of the CCW attended the Provincial Milk Board Hearings in Vancouver. The CCW brief at the hearings stated that the "brunt of higher costs can and must be borne by the distributors."

Expressing concern for children's health, the brief remarked that society should be encouraging children of all backgrounds "to be drinkers of milk instead of consumers of pop." Marie Godfrey, President of the BC branch of the CCW, argued that Vancouver was more expensive to live in than any other Canadian city, excepting Montreal. She suggested that, "as women, we are becoming more and more alarmed at the general trend indicated by prices of basic foods jumping two and three cents a week." 60

$\mathrm{CP}$ women's activism and discourse suggests that a combination of maternalist and socialist views shaped their pro-family ideology. CP members drew a clear link between women, child rearing, and consumption. They presented these issues as key elements of women's unpaid work in the home and used these as stimulants to women's political action and consciousness. Communist women connected consumption with class issues: because working-class women purchased products for the home, they were therefore uniquely suited to using their purchasing power to strike a blow against high prices. This was part of left women using an essentialist argument in a strategic manner, using conservativesounding arguments to draw in more conservative people.

At the same time, Canadian left women genuinely endorsed a maternalist viewpoint. As Peter Campbell and Deborah Gerson have suggested, they utilized family-centered rhetoric in radical ways. American CP women, and Canadians like Rose Henderson, used the terms "worker" and "mother" interchangeably. Many left women engaged in protest outside of the home, in order to improve life for women and families inside of the home. ${ }^{61}$ Jacqueline Castledine has argued that this ideology - "community feminism" - was a prominent perspective among many left women during the late-1940s and 1950s. In upholding the home and family, left women's views were of a piece with those of progressives from earlier decades. ${ }^{62}$ 
Of course, the maternalist viewpoint was not the only tool that $\mathrm{CP}$ women used to combat sexism and class exploitation. Evidence exists that there were diverse voices in the party. By the late-1940s, many in the American CP women like Elizabeth Gurley Flynn and Betty Millard as well as some men - had begun to recognize that male supremacy was a problem and some even argued that they needed to make the battle against male supremacy a specific priority. Articles that spoke out against male supremacy, written by women like Flynn and Claudia Jones, began to appear in the party newspaper. These pieces did not utilize a maternalist ideology. Instead, the American CP emphasized the need to allow women to work outside of the home and to find solutions to the "double day" of labour for working women. ${ }^{63}$ In spite of this, the American CP never fully rid itself of the scourge of sexism. This more sustained battle against misogyny and male supremacy never materialized in Canada, perhaps because, as Joan Sangster has noted, there were few women in the CPC who were specifically interested in women's issues. ${ }^{64}$ Regardless, after 1956, the CP declined as a force worldwide and its pronouncements lost what power they previously had in both Canada and the U.S.

\section{CCF Women and Consumption: Resistance and Accommodation?}

CCF women were less concerned about the issue of high prices, possibly because the CCF's ideology was more moderate and accommodating to the established order. Nonetheless, social democrats offered some trenchant commentary surrounding this issue. A draft of the CCF's platform for 1947 stated that the party supported maintaining price and wage controls. ${ }^{65}$ Like the $\mathrm{CP}$, the CCF favoured a comprehensive national housing policy. In an earlier comment, CCF member Grace MacInnis noted that, although more than ninety percent of housewives had stoves and more than eighty-five percent had a radio, only seventy-five percent of women had an electric iron and only twenty-seven percent had a refrigerator. 66 "Today's housewife," MacInnis asserted, "cannot afford efficiency. Her husband's wages are too low or he is unemployed." 67 As Joy Parr has argued, consumption, post-war affluence, and household technology were closely linked to politics and ideology.68 Thus, MacInnis implied that class was crucial to one's ability to participate in modern consumer society. ${ }^{69}$

The CCF's ideology tells us much about their views on consumption. MacInnis contrasted Britain under the Labour Party with Canada under the Liberals. Writing on "the cost of decontrol," she noted that, "British people are now drinking nearly $50 \%$ more milk than before the war." She quoted a study arguing that British maternal and infant mortality rates had reached the lowest levels ever recorded. Conversely, the cost of items like food, fuel, clothing and home furnishings had risen in Canada. ${ }^{70}$ No doubt MacInnis's comments regard- 
ing Clement Atlee's Britain contained a good amount of wishful thinking: the CCF celebrated social democracy in other nations rather uncritically. The British Labour Party, and its forerunner the Fabian Society, held a strong influence on CCF policy. ${ }^{71}$

Presenting themselves as consumers and activists, social democratic women advocated a platform of reform. A statement written in the late-1940s, entitled "CCF Women as Consumers," suggested that the party should be taking the lead in "securing enough production of the goods families need at a price within the reach of all." To achieve this goal, the party needed to push for a national consumer organization in Canada that would bring together individuals from all walks of life. The CCF should have representation on this organization; its goal would be to decide on what "government action" would remedy the problem of high prices. Like the CP, the CCF's statement emphasized the problem of high milk prices; it also argued that children's clothing cost too much and that rents were too high across the nation. The CCF emphasized winning elections and achieving state power as the means toward a better society: government intervention and increasing bureaucracy could solve the problems of modern society. This was very much in keeping with the CCF's focus on electoral politics. The statement did not endorse the HCA's program, seeing it as an "undemocratic" Communist front. ${ }^{72}$ Even more than in the CP, the CCF used maternalism strategically to bring in new voters and party members.

Many CCF members subscribed to anti-communist views. Ontario activist Marjorie Mann was a particularly strong advocate against the $\mathrm{CP}$ in its various guises. In the atmosphere of the Cold War, this was a common stance for those on the social democratic left. ${ }^{73}$ In a letter to Morden Lazarus, a prominent unionist and Ontario CCF activist, Mann expressed her misgivings about the Housewives Consumers' Association and its platform. Noting Grace MacInnis's aversion to the HCA, Mann asserted that the HCA's President and two important supporters were members of the LPP or "fellow travelers, although they deny it periodically." The CCF, Mann argued, should have nothing to do with the HCA: "their methods of work are completely opposite to ours ... if we are going to build the CCF we simply cannot follow their methods." 74 In a letter to Lucy Woodsworth, widow of the party's first federal leader J.S.

Woodsworth, Mann lambasted Communists for their alleged "dishonesty, maneuvering" and "use of personal relationships" in establishing the HCA in Ontario. ${ }^{75}$ Mann and Grace MacInnis advocated that the CCF join with the supposedly non-partisan Consumers Association of Canada (CAC) in order to find a platform to push for price limits on milk, bread, butter, and meat. ${ }^{76}$ They hoped that joining the CAC would allow CCF women access to membership lists whereby they could convert more women to social democratic ideology. ${ }^{77}$ This did not prove to be the case. ${ }^{78}$ 
Despite the anti-communism of many social democrats, CCF women's rhetoric on consumption was similar to the CP's. Both groups made links between consumption, anti-war activism, and class. A pamphlet produced shortly after the end of World War II shows the CCF response to rising prices. The item noted that, "women's homes were in danger" because the prices of foods like milk and butter had risen. The pamphlet emphasized that, during the war, women had undertaken "many sacrifices in order for the Allies to win." Women were therefore entitled to share in the fruits of capitalist prosperity. Women, the author argued, should come to party meetings, join the CCF, and work to elect the party's candidates. ${ }^{79}$

Individual CCF members endorsed these views. Muriel Campbell, later to run for the Legislative Assembly in BC, argued that women needed to rid themselves of the "nylon mentality," which gave hours to obtaining small material comforts but did not give any thought to issues like "housing, juvenile delinquency, jobs and wages." 80 Campbell expressed a fairly common perspective among politicized left women: a critique of other women as being frivolous, vain, and immature. Offering a similar viewpoint, long time CCF member Claire McAllister declared that, "opinion is strong that we should be doing more than we are in the way of restricting consumption." In a climate of post-war scarcity, women should be saving foodstuffs to send to an impoverished European populace and to Canada's poor families. "There are many things which are not rationed which we should be saving and sharing," McAllister asserted. ${ }^{81}$

The views of the CP and CCF coincided in many ways. In an article entitled "Hitting Below the Belt," Con Stuart argued that, "you now need an income of $\$ 43.15$ a week to maintain a family of four on an adequate diet and proper living conditions. The average wage is $\$ 31.68$ a week. Social assistance for a family of four is $\$ 14.35$ a week." Stuart offered a sustained critique of capitalist wages and consumption from a gendered perspective. He noted that the Mothers' Pension 'is $\$ 40.00$ a month and $\$ 7.50$ for each child, so if she has three children, she must feed, clothe and house them on $\$ 15.00$ a week." The danger of malnutrition existed when a family of four spent fewer than $\$ 13.00$ per week on food. ${ }^{82}$ The author also presented a discordant view on women's roles in capitalist society. "It is hard on those women who must work and keep house at the same time; they cannot go around hunting bargains in the chain stores. Nor have they time to prepare the cheaper, and often more nourishing, type of foods" he noted. Stuart contended that "single girls are working for as little as $\$ 13.00$ a week; they depend on their relatives and friends to help them out. These are the conditions that keep psychiatrists busy." 83 This view was not typical for CCF men. Like in the CP, social democratic men did not see consumption as an important issue. 
Expressing a similar view, Bridget O’Malley wrote a column for the CCF News, entitled "Sisters Under the Skin," which appeared in certain weeks during the late-1940s. O’Malley's material was not usually overtly political. On one occasion, however, she went beyond her typical line of thought in remarking on how the BC Prices Board accused housewives of hoarding butter. In defence of housewives, she stated that, "every mother knows that you cannot keep a growing child in proper condition on half a pound of butter a week. No matter what social service may say about milk, you need the butter too." Forging a link between radicalism, consumption, and anti-war activism, O'Malley wondered, "what are we keeping them [children] healthy for - to fight another war to protect Canada Packers' profits?” J.S. McLean, President of Canada Packers, she argued, would maintain the current price if he could and then blame housewives for hoarding butter." 84 CCF women mobilized to defend their children, families, and communities against the incursions of war and capitalism, much as CP women did. Maternalism acted as a spur to Left women's consciousness, both in allowing them to present different views from their male counterparts and in using motherhood as a justification for political activism outside of the home.

In the March 1948 meeting of the Vancouver CCF Women's Council, the organization seconded O'Malley's point on the connections among anti-war activism and the production and consumption of goods. The council passed a resolution urging the Canadian government to add its voice "to that of other countries who desire a more even distribution of the wealth of the world at peace." The Women's Council also asked the Canadian government to speed up the production and distribution of essential goods. International issues were important here: CCF women asserted that the unequal distribution of goods adversely affected people in poorer nations. ${ }^{85}$ Social democratic women argued that their role as mothers led them to take on a higher calling, as the symbolic mothers to all of the world's children in the face of hunger and deprivation. This argument was in keeping with the history of maternalism among activist women. A significant number of Left women borrowed elements from maternal feminism and other, earlier women's movements. As Carol Bacchi has shown, suffragists from the 1890-1920 period asserted that women needed to bring the virtues of nurturance and caring into the public sphere of politics and economics to save it from men who had done a poor job of administering society. ${ }^{86}$ CCF women tried to break down divisions between public and private in making the home a site of resistance to the dominant system. For CCF women, their activity in this area tended to be more on the level of rhetoric: the CCF endorsed the values of community and female consciousness, but neither their statements, nor their actions, were as radical as those of the CP. This reflected the CCF's strategy at appearing "mainstream" in order to attract liberal and even conservative voters and supporters to the CCF. 
Discourse surrounding production and consumption became far less frequent in CCF publications as the 1950s progressed. Indeed, women's organizations and women's activity in the CCF declined throughout the 1950s and early-1960s, a legacy of the party becoming increasingly conservative and moving away from a maternalist analysis. ${ }^{87}$ Eileen Robins wrote on consumption and the union label in 1958; this was the last significant statement by a CCF woman on consumption for at least a decade. Robins argued that there should be a program of publicity surrounding which dress and cigarette makers had union labels. Women, she argued, were the main purchasers of dresses and cigarettes. Auxiliaries and women's clubs were natural outlets for educational programs surrounding the union label. She asked the question "what can we wives and mothers do?" and responded that women needed to "make the effort to 'buy union' if we possibly can" and to "keep on demanding that the goods we buy are union labelled." If every "union consumer" demanded that stores carry union-made clothing and cigarettes, this would then have a significant effect. ${ }^{88}$

\section{CCF Women: Consumption as a Political Priority}

Why were protests around consumer issues less important for female social democrats? Joan Sangster notes that CCF women's organizations were affiliated with more moderate groups like the Local Councils of Women. Similarly, the CCF was a less ideologically "rigid" party than the CP and attracted a diverse membership with a variety of views. Some CCF members wanted to work with the CP in organizations like the HCA. Others, probably a majority, were anticommunist, and forbade any contact with groups that had "red" associations. This proved to be a negative option for several reasons. First, it left social democratic women without an organization to promote their views on consumption. Second, the attacks on Communists led to the final marginalization of the CP. Lastly, with the Communists destroyed, the Canadian political spectrum moved to the right and it became the CCF's turn to be demonized as anti-capitalist and radical. The Winnipeg Declaration of 1956 , where the party repudiated the earlier, somewhat more radical Regina Manifesto, and the creation of the New Democratic Party in 1961, exacerbated centrist trends within Canadian social democracy. 89

Working with the CP, despite its faults, would have been a more productive venture. CCF and CP supporters might have formed a "left-wing bloc" to challenge the pro-capitalist forces in Canada; however, this was not to be. Working with Communists represented a real legal and economic risk for those social democrats and liberals who chose to ally with the CP. In both Canada and the U.S., allying with Communists - even briefly and indirectly - led to job loss, social ostracism, personal stress, and suicide. ${ }^{90}$ Even with this in mind, it still 
seems that the CCF made a mistake in moving to the centre. Choosing the more conservative option hurt women's advancement: working with the CAC led to the end of consumption and high prices as issues of concern for the CCF. The CP's activism around consumption was more productive; it provided women with a site of struggle where conservative-sounding views could be used to promote leftist ideology. The fact that the CP used maternalist ideology more frequently, and with greater vigour than previously, led to a stronger women's sphere within the party. The CCF did not use maternalism to the same extent; this, in part, led to women's issues becoming marginal within the party.

\section{What is to be Done with Maternalism and Consumption?}

Left women's activism surrounding consumption and maternalism was twosided. On the one hand, these women used maternalism as a kind of "strategic essentialism" to appeal to women, as mothers, who would not otherwise have been sympathetic to a leftist argument. On the other hand, many left women did not see the maternal role as inferior. Kathleen Brown's work on "Mother" Ella Reeve Bloor helps us to understand how production and consumption operated in left women's discourse. Brown argues that the home, for Left women, was one site where the class struggle could be played out: they viewed it as the locus of their "womanly radicalism" in the campaign against high prices. ${ }^{91}$ Canadian socialist Rose Henderson held similar views; Peter Campbell has argued that Henderson's feminist ideology was different from both first-wave, maternal feminism and second-wave feminism. ${ }^{92}$ Women's activism during the 1930-1960 period was a kind of "one and a half" wave of feminism that laid the groundwork for the rise of the second wave. As Jacqueline Castledine has suggested, the Cold War and "McCarthyism" did not completely destroy the left in the 1940s and 1950s; activists from the earlier period sowed the seeds for the "New Left" of the 1960s. ${ }^{93}$ This adds to the work of historians like Joan Sangster and Julie Guard who focused primarily on the 1950 s. ${ }^{94}$ In partial contrast to Sangster, this paper has suggested that the use of maternalism during the 1950s increased women's activism in the CP and CCF, and also prefigured the growth of secondwave feminism. ${ }^{95}$

There was much debate in left circles over the presence of a separate women's space. Some social democratic women opposed separate female groups and advocated that left women work with men in fighting all forms of oppression. ${ }^{96}$ Other women felt differently: they saw themselves as radical versions of what has been called the "citizen consumer." These women, in both the CP and $\mathrm{CCF}$, attacked the high cost of living - a perspective that many on various points of the ideological spectrum agreed with - and used consumption as a springboard toward reforming the worst excesses of capitalism. This vision of con- 
sumption contrasted with other, more conservative, views exemplified by the "purchaser consumer," or the "citizen as consumer." Adherents of this viewpoint, which predominated in North America and elsewhere after World War II, endorsed the acquisition of goods for all as well as a higher standard of living for more people. This popular view ignored class, racial, and gender-based realities. ${ }^{97}$ The left-wing vision of women as radical consumers was a minority viewpoint. Still, in their activism against high prices, left wing and working-class women helped to birth a new vision of women's empowerment. They largely took over the leadership of the women's movement during the 1945-1960 years, a time when middle and upper class feminists had achieved many of their goals. ${ }^{98}$

$\mathrm{CP}$ and CCF women did not convince federal or provincial governments to lower prices of staple goods or rent. Rather, with the rise of the welfare state and increasing affluence, people of various classes had more money to spend on necessities and luxuries, even as inequality persisted. With the economic downturn of the mid-1970s, and the subsequent rise of neo-liberal ideology, poverty increased. Today, rampant consumption continues to beset society and there is no end in sight to rising prices. As Mildred MacLeod suggested at the outset, Communist and CCF women showed great "ingenuity" in critiquing the class-specific aspects of consumption. Using a maternalist ideology may have been "essentialist," but it allowed left women to promote gendered arguments to mainstream society and to prod the left toward pro-woman arguments. In this way, maternalism - as a strategy for women's empowerment - was useful for Canadian left women during the 1940s and 1950s. Conservative-sounding rhetoric around women's issues did not lead to women being pushed back into the home. Indeed, with the onset of second-wave feminism, the reverse occurred.

\section{NOTES}

Acknowledgements: The author thanks Mary Franks and the Editors at Left History for their help with this article. He also thanks the two anonymous reviewers for their very helpful comments on an earlier draft of the article. Finally, he thanks John Allison, Hilary Earl, Darren Ferry, Mark Crane and Erin Dokis, Jane Power and Jack O’Dell, and especially Bryan Palmer, Joan Sangster, and Michelle Martin for their help and support over the years.

${ }^{1}$ Robert Bothwell, Ian Drummond, and John English, Canada Since 1945: Power, Politics, and Provincialism, Revised Ed. (Toronto: University of Toronto Press, 1989), 54-55; Magda Fahrni, "Counting the Cost of Living: Gender, Citizenship, and a Politics of Prices in 1940s Montreal," Canadian Historical Review 83:4

(December 2002): 486-487. 
2 The entire histories of the CP and CCF parties are too complex to be fully outlined here. For background on the CP, see especially Ian Angus, Canadian Bolsheviks: The Early Years of the Communist Party of Canada, $2^{\text {nd }}$ ed. (Victoria, BC: Trafford Publishing, 2004); Ivan Avakumovic, The Communist Party of Canada: A History (Toronto: McClelland and Stewart, 1975); Norman Penner, Canadian Communism: The Stalin Years and Beyond (Toronto: Methuen, 1988). On the CCF, see Michiel Horn, The League for Social Reconstruction: Intellectual Origins of the Democratic Left in Canada, 1930-1942 (Toronto: University of Toronto Press, 1980); Alan Whitehorn, Canadian Socialism: Essays on the CCF-NDP (Toronto: Oxford University Press, 1992); Walter D. Young, The Anatomy of a Party: The National CCF, 1932-61 (Toronto: University of Toronto Press, 1969). For an overview of women's experiences in both the CP and CCF, see Joan Sangster, Dreams of Equality: Women on the Canadian Left, 1920-1950 (Toronto: McClelland and Stewart, 1989).

3 CCF News, 28 February 1951.

${ }^{4}$ Ibid.

5 The HCA had its origins in the pre-World War II organization, the Housewives League (HWL), established in Vancouver in 1937 by Liberal Party women. The HWL initially accomplished little and CP women soon took over the organization and used it as a vehicle to combat high prices of goods. The HWL dissolved after the end of World War II, but in 1947, with the federal government's removal of price controls, CP women set up the HCA. It had branches everywhere in Canada, but was particularly strong in urban Ontario and Western Canada. See Simon Fraser University Archives, Women's Labour History Collection, (SFU, WLHC), Interview with Effie Jones, Summer 1979, with Sara Diamond. See also Julie Guard, "Women Worth Watching: Radical Housewives in Cold War Canada," and Mercedes Steedman, "The Red Petticoat Brigade: Mine Mill Women's Auxiliaries and the Threat from Within, 1940s-70s," in Gary Kinsman, Dieter K. Buse, and Mercedes Steedman, eds., Whose National Security? Canadian State Surveillance and the Creation of Enemies (Toronto: Between the Lines, 2000), 77-79, 55-68; Joy Parr, Domestic Goods: The Material, the Moral, and the Economic in the Postwar Years (Toronto: University of Toronto Press, 1999), 90-91; Sangster, Dreams of Equality, 185-191.

${ }^{6}$ An explanation of juvenile delinquency can be found in Mary Louise Adams, The Trouble with Normal: Postwar Youth and the Making of Heterosexuality (Toronto: University of Toronto Press, 1997); Joan Sangster, Girl Trouble: Female Delinquency in English Canada (Toronto: Between the Lines, 2002).

7 British Columbia was arguably the most consistently radical province in English Canada, and this was certainly the case during the 1945-1960 period. Similarly, the City of Vancouver possessed a powerful labour, socialist, and Communist movement during this, and earlier, periods. See Elaine Bernard et al., 
Working Lives: Vancouver, 1886-1986 (Vancouver: New Star Books, 1986); Benjamin Isitt, Militant Minority: British Columbia Workers and the Rise of a New Left, 1948-1972 (Toronto: University of Toronto Press, 2011), chapter one; Paul Phillips, No Power Greater: A Century of Labour in BC (Vancouver: BC Federation of Labour/Boag Foundation, 1967).

8 This definition of "strategic essentialism" draws on Susan Prentice, "Workers, Mothers, Reds: Toronto's Postwar Daycare Fight,” Studies in Political Economy 30 (Autumn 1989): 115-141. On maternalism as strategy, see also Irene Howard, “'The Mothers' Council of Vancouver: Holding the Fort for the Unemployed, 1935-38," BC Studies 69-70 (Spring-Summer 1986): 249-287.

${ }^{9}$ For these arguments, I am indebted to Temma Kaplan, "Female Consciousness and Collective Action: The Case of Barcelona, 1910-1918," Signs 7:3 (Spring 1982): 565-566.

10 Ibid, 566.

11 A word is necessary regarding the sources used here. In short, they have their limitations. I draw heavily on the "official" newspapers of the CP and CCF parties as well as on publications that were prepared specifically for propaganda purposes for both movements. These sources largely presented the "party line" on issues, although there was some debate over certain topics. We will never know if the opinions and letters published in the CP and CCF press were solicited or spontaneous. The Communist press, in particular, only published positive letters; however, the fact that many women wrote in, and that the parties published material relating to women, suggests that maternalist arguments had some resonance for left women.

12 The Cold War refers to the ideological struggle waged for world supremacy between the Western, capitalist nations, led by the United States, and the Communist bloc of nations, led by the Soviet Union. For an overview of the Cold War in the Canadian context, see Reg Whitaker and Gary Marcuse, Cold War Canada: The Making of a National Insecurity State, 1945-1957 (Toronto: University of Toronto Press, 1994). In the U.S. context, many titles could be cited. For an overview of American anti-communism, see Ellen Schrecker, Many Are the Crimes: McCarthyism in America (Boston: Little, Brown, 1998).

13 On "maternalism," see especially Linda Gordon, Pitied but Not Entitled: Single Mothers and the History of Welfare, 1890-1935 (Cambridge: Harvard University Press, 1994); Seth Koven and Sonya Michel, eds., Mothers of a New World: Maternalist Politics and the Origins of Welfare States (New York: Routledge, 1993); Molly Ladd-Taylor, Mother-Work: Women, Child Welfare, and the State, 1890-1930 (Urbana: University of Illinois Press, 1994).

14 Dana Frank, Purchasing Power: Consumer Organizing, Gender, and the Seattle Labor Movement, 1919-1929 (New York: Cambridge University Press, 1994). 15 Tarah Brookfield, Cold War Comforts: Canadian Women, Child Safety, and Global 
Insecurity, 1945-1975 (Waterloo, ON: Wilfrid Laurier University Press, 2012), 7175 and passim. The "Old Left" refers to the communist and social democratic left of the period from roughly 1930-1959. This was, in its Canadian essence, the CP and CCF along with other, smaller parties that espoused similar views about the working class and its mission to overthrow capitalism and install a more humane, socialist system. The "New Left" refers to the many groups of left radicals who emerged during the early-1960s and in subsequent years. In contrast to their counterparts from earlier decades, the New Left did not emphasize workers as the force for social change, but instead upheld the "new social movements," second-wave feminists, gay and lesbian activists, environmentalists, and students to name but a few as the leading forces to effect a new society. See Isitt, Militant Minority, 109-137; Bryan D. Palmer, Canada's 1960s: The Ironies of Identity in a Rebellious Era (Toronto: University of Toronto Press, 2009).

16 Nan Enstad, Ladies of Labor, Girls of Adventure: Working Women, Popular Culture, and Labor Politics at the Turn of the Twentieth Century (New York: Columbia University Press, 1999); Kathy Peiss, Cheap Amusements: Working Women and Leisure in Turn-of-the-Century New York (Philadelphia: Temple University Press, 1986); Kathy Peiss, Hope in a Jar: The Making of America's Beanty Culture (New York: Owl Books, 1999); Cynthia Wright, "Feminine Trifles of Vast Importance: Writing Gender into the History of Consumption," in Franca Iacovetta and Mariana Valverde, eds., Gender Conflicts: New Essays in Women's History (Toronto: University of Toronto Press, 1992), 229-260. See also Elaine Abelson, When Ladies Go AThieving: Middle-Class Shoppers in the Victorian Department Store (New York: Oxford University Press, 1989); Susan Porter Benson, Counter Cultures: Saleswomen, Managers, and Customers in American Department Stores, 1890-1940 (Urbana: University of Illinois Press, 1989); Erika Diane Rappaport, Shopping for Pleasure: Women in the Making of London's West End (Princeton: Princeton University Press, 2000). A study of the ideological viewpoint of Canadian department store owners can be found in Donica Belisle, Retail Nation: Department Stores and the Making of Modern Canada (Vancouver: University of British Columbia Press, 2011).

17 Jacqueline B. Castledine, Cold War Progressives: Women's Interracial Organizing for Peace and Freedom (Urbana: University of Illinois Press, 2012). For background on the various "generations" of women's activism in Canada, see Linda Kealey, Enlisting Women for the Cause: Women, Labour, and the Left in Canada, 1890-1920 (Toronto: University of Toronto Press, 1998); Sangster, Dreams of Equality, 55164; Sangster, Transforming Labour: Women and Work in Post-War Canada (Toronto: University of Toronto Press, 2010), 233-268.

18 For the view that the early Cold War era, especially the 1950s, was a conservative time see Elaine Tyler May, Homeward Bound: American Families in the Cold War Era, Revised Ed. (New York: Basic Books, 1999). For perspectives that show a more complex viewpoint see especially Castledine, Cold War Progressives; Magda 
Fahrni, Household Politics: Montreal Families and Postwar Reconstruction (Toronto: University of Toronto Press, 2005); Joanne Meyerowitz, Ed., Not June Cleaver: Women and Gender in Postwar America, $1945-1960$ (Philadelphia: Temple University Press, 1994).

19 Sangster, Dreams of Equality, 234-238; Lynne Segal, Is the Future Female? Troubled Thoughts on Contemporary Feminism (London: Virago, 1987), 199 and passim. 20 Kathleen A. Brown, “The 'Savagely Fathered and Un-Mothered World' of the Communist Party U.S.A.: Feminism, Maternalism, and Mother Bloor," Feminist Studies 25:3 (Autumn 1999): 539, 560; Peter Campbell, Rose Henderson: A Woman for the People (Montreal and Kingston: McGill-Queen's University Press, 2010). See also the works cited in fn 15. I part company with Brown's viewpoint in one sense. She argues that "Mother" Bloor possessed a different, and more radical, ideology than maternalism, while I attempt to reclaim maternalist ideology as a useful - and potentially radical - vehicle for the left and feminism.

21 Kaplan, "Female Consciousness and Collective Action," 565-566. For an examination of how right-wing women used motherhood and maternalism see Margaret Power, Right-Wing Women in Chile: Feminine Power and the Struggle Against Allende, 1964-1973 (University Park, PA: Pennsylvania State University Press, 2010).

22 Brown, "The 'Savagely Fathered and Un-Mothered World," 551-552.

23 Steedman, "The Red Petticoat Brigade." The term "embeddedness" is from Maureen G. Reed, Taking Stands: Gender and the Sustainability of Rural Communities (Vancouver: University of British Columbia Press, 2003).

${ }^{24}$ From June 1940 until August 1943, the Communist Party of Canada was an illegal organization. In 1943, Prime Minister William Lyon Mackenzie King agreed to make membership in the CP legal again, on condition that it change its name to the Labor Progressive Party [LPP]. Presumably, this sounded less threatening to the capitalist status quo than "Communist Party of Canada." In October 1959, following the de-Stalinization of the Canadian CP, the name "Communist Party of Canada" was retained. See Avakumovic, The Communist Party in Canada, 142-152, 235.

25 University of Toronto, Thomas Fisher Rare Book Library, Robert Kenny Collection, Box 45a. Unpublished MSS, "Woman," n.a., n.d. I assume from the mention of "warmongers and profiteers" that the author wrote the manuscript during the aftermath of World War II, likely during the late-1940s. The report also references Effie Jones's candidacy for public office. CP member Jones ran for the Mayoralty in Vancouver in 1947 and 1948 and subsequently ran, unsuccessfully, for city council and school board on several occasions during the 1950s. On Jones see Sangster, Dreams of Equality, 179; "Visions of the New World Order: Women and Gender in Radical and Reactionary Movements in Post-World War II Western Canada," PhD Dissertation, Trent University, 2006, 
chapter one. The use of Canadian nationalism also reflected the CP's attempt to appeal to "mainstream" Canadians, who otherwise feared communist ideology. Opposition to American encroachment on Canada was a fairly widely held viewpoint among many Canadians across the political spectrum during the postWorld War II years. See Stephen Azzi, Walter Gordon and the Rise of Canadian Nationalism (Montreal and Kingston: McGill-Queen's University Press, 1999); Jose Igartua, The Other Quiet Revolution: National Identities in English Canada, 1945 71 (Vancouver: University of British Columbia Press, 2006).

${ }^{26}$ Chunn, Jones, and Anderson were all prominent CP women who were living in the Vancouver area at this time.

${ }^{27}$ It is difficult to give an exact number of women in the Canadian Communist movement. The entire membership of the CPC during the 1930-1960 period was not more than 10,000, although "fellow travelers" - those who sympathized with the party but did not officially join it - would have been substantially larger, perhaps numbering in the hundreds of thousands. Women were perhaps thirty percent of the total membership of the party. See Avakumovic, The Communist Party in Canada, 1-17; "Visions of the New World Order," introduction.

28 Pacific Tribune, 5 November 1948.

${ }^{29}$ NAC, CSIS Fonds, Bulletin, Tim Buck to all Provincial LPP Committees, Editors of the "labor press," and the National LPP Executive Committee, 10 February 1948.

30 Tim Buck, Keep Canada Independent (Toronto: Progress Books, 1948). Summary of Report to Meeting of Labor-Progessive Party, National Committee, Toronto, 6-9 January 1948, 4-5, 14-15.

31 For a critique of Marxist attitudes toward women and gender see Todd McCallum, "Not a Sex Question?” The One Big Union and the Politics of Radical Manhood," Labour/Le Travail 42 (1998): 15-54. See also Kealey, Enlisting Women for the Cause; Janice Newton, The Feminist Challenge to the Canadian Left, 1900-1918 (Toronto: University of Toronto Press, 1995); Sangster, Dreams of Equality for further information on the Canadian CP's treatment of women, too complex to fully explain here.

32 Pacific Tribune, 21 June 1946.

33 Ibid.

34 Pacific Tribune, 26 July 1946.

35 Morgan was a key CP and trade union activist in BC Her husband Nigel Morgan was the President of the IWA during the 1940s and later headed the BC branch of the Communist Party of Canada. See Sangster, Dreams of Equality, 188; "Visions of the New World Order," chapter one and passim. The IWA was arguably the most important CP-led union in British Columbia and was a major player in radical protest in BC See Isitt, Militant Minority; Jerry Lembcke and William M. Tattam, One Union in Wood: A Political History of the International 
Woodworkers of America (Madeira Park, BC: Harbour Publishing, 1984); Andrew Neufeld and Andrew Parnaby, The IWA in Canada: The Life and Times of An Industrial Union (IWA Canada/New Star Books, 2000).

36 Pacific Tribune, 26 July 1946.

37 Pacific Tribune, 4 October 1946.

38 National Archives of Canada [NAC], Canadian Security and IS Fonds, Letter, Mrs. Rae Lucock, President, Toronto Housewives' Consumers Association, to Prime Minister William Lyon Mackenzie King, 21 April 1948. Lucock was later expelled from the CCF because of her insistence that the party collaborate with the CP-led HCA; she continued her activism with the Congress of Canadian Women (CCW). See Dean Beeby, "Women in the Ontario CCF, 1940-1950," Ontario History LXXIV, No. 4 (December 1982): 273-275; Sangster, Dreams of Equality, 188-189.

39 Ibid. For a précis of the HCA's program see also NAC, CSIS Fonds, "Proposed Program to be Presented to the Housewives' and Consumers' Federation of Canada Convention, April 15 to 18, 1948, Ottawa."

40 This terminology is borrowed from Varda Burstyn, The Rites of Men: Manhood, Masculinity, and the Culture of Sport (Toronto: University of Toronto Press, 1999). 41 Pacific Tribune, 4 October 1946.

42 See especially Louise I. Carbert, Agrarian Feminism: The Politics of Ontario Farm Women (Toronto: University of Toronto Press, 1995); Monda Halpern, And On That Farm He Had a Wife: Ontario Farm Women and Feminism, 1900-1970 (Montreal and Kingston: McGill-Queen's University Press, 2001).

43 John Agnew, Making Political Geography (New York: Oxford University Press, 2002); Agnew, Place and Politics: The Geographical Mediation of State and Society

(Boston: Allen and Unwin, 1987), 25-61.

44 Pacific Tribune, 18 October 1946.

45 Pacific Tribune, 25 October 1946.

46 Pacific Tribune, 8 November 1946. On the CP and rural concerns, see Lowell K. Dyson, Red Harvest: The Communist Party and American Farmers (Lincoln: University of Nebraska Press, 1982); Robin D.G. Kelley, Hammer and Hoe: Alabama Communists During the Great Depression (Chapel Hill: University of North Carolina Press, 1990). See also Reed, Taking Stands.

47 Pacific Tribune, 29 November 1946.

48 Pacific Tribune, 17 January 1947.

49 Ibid.

50 Irving Abella, Nationalism, Communism and Canadian Labour: The CIO, the Communist Party, and the Canadian Congress of Labour, 1935-1956 (Toronto:

University of Toronto Press, 1973), 221-222. For a more critical look at the CP's actions see Aileen S. Kraditor, "Iimmy Higgins": The Mental World of the American 
Rank and File Communist, 1930-1958 (New York: Greenwood Press, 1988).

${ }^{51}$ For another perspective on this in the U.S. context see Susan Porter Benson, Household Accounts: Working-Class Family Economies in the Interwar United States (Ithaca and London: Cornell University Press, 2007), 27-42.

52 Pacific Tribune, 11 April 1947. On labourism see Craig Heron, "Labourism and the Canadian Working Class,” Labour/Le Travail 13 (Spring 1984): 45-75.

53 Mary Inman, In Woman's Defence (Los Angeles: Committee to Organize the Advancement of Women, 1940). On Inman see Kate Weigand, Red Feminism: American Communism and the Making of Women's Liberation (Baltimore and London: Johns Hopkins University Press, 2001), 28-55. Having been expelled from the party in 1941, Inman herself was not involved in the debates over the "woman question" during the 1950s, or in the battles that led to second-wave feminism in subsequent decades. See also the remarks by Lise Vogel, Gerald Horne, Van Gosse and Dorothy Healey, and Bettina Aptheker, as well as Weigand's "Reply to Critics," in "Red Feminism: A Symposium," Science and Society 66:4 (Winter 20022003): 498-535.

54 Pacific Tribune, 9 January 1948. On Jones, see fn 25.

55 Pacific Tribune, 2 July 1948.

56 Kaplan, "Female Consciousness and Collective Action," 545-566.

57 Pacific Tribune, 12 September 1947.

58 The CCW was initially founded in 1948 as an affiliate of the Women's

International Democratic Federation [WIDF], an international group made up of Communist bloc women's organizations. In 1949, with the issues of high prices being an important one for CP women, a number of HCA supporters re-institute the CCW at the national level in Canada. See Sangster, Dreams of Equality, 189.

59 Pacific Tribune, 28 July 1950.

60 Pacific Tribune, 11 August 1950.

61 Campbell, Rose Henderson: A Woman for the People, 5-8, 29-37 and passim;

Deborah Gerson, “'Is Family Devotion Now Subversive?' Familialism Against

McCarthyism," in Joanne Meyerowitz, ed., Not June Cleaver: Women and Gender in Postwar America, 1945-1960 (Philadelphia: Temple University Press, 1994), 151172.

62 For the U.S. context, see Castledine, Cold War Progressives, 50-60 and passim; Weigand, Red Feminism, chapter four.

63 Weigand, Red Feminism, chapter four.

64 Sangster, Dreams of Equality.

65 CCF News, 2 January 1947.

66 MacInnis was the daughter of J.S. Woodsworth, one of the CCF's founders, and its first federal leader. See Ann Farrell, Grace MacInnis: A Story of Love and 
Integrity (Markham, ON: Fitzhenry and Whiteside, 1994).

67 CCF News, 14 February 1946.

68 Parr, Domestic Goods, 34-37.

${ }^{69}$ CCF News, 14 February 1946.

70 CCF News, 7 August 1947.

71 Michiel Horn, The League for Social Reconstruction: Intellectual Origins of the

Democratic Left in Canada, 1930-1942 (Toronto: University of Toronto Press, 1980).

72 National Archives of Canada [NAC], Marjorie Mann Papers, Box 2, File 2.

Unpublished MSS, "CCF Women as Consumers," n.a., n.d. I assume from the context of the statement, and from the other material in the collection that deals with the same topic, that the statement was written around 1947-48.

73 For commentary on this in particular contexts see Isitt, Militant Minority; Christina J. Nichol, "In Pursuit of the Voter: The British Columbia CCF, 194551," in J. William Brennan, ed., "Building the Co-operative Commonwealth": Essays on the Democratic Socialist Tradition in Canada (Regina: Canadian Plains Research Centre, 1984), 123-135; Richard Gid Powers, Not Without Honor: The History of American Anti-Communism (New York: Free Press, 1995).

74 NAC, Marjorie Mann Papers, Box 2, File 2. Letter, Marjorie Mann to Morden Lazarus, 23 June 1947.

75 NAC, Marjorie Mann Papers, Box 2, File 2. Letter, Marjorie Mann to Lucy Woodsworth, n.d. (likely 1947, given the mention of the HCA, which was formed in 1947).

76 This organization was established in 1947 with a federal government subsidy. It was meant to be an advocacy group for consumers that would conduct price surveys and lobby the federal government on behalf of Canadian consumers. With its connections to the federal state and centrist outlook, it was a largely toothless body. See Sangster, Dreams of Equality, 220-221.

77 NAC, Marjorie Mann Papers, Box 2, File 2. Letters, Grace MacInnis to Marjorie Mann, 12 November 1947, 19 January 1948.

78 Indeed, Cold War anti-communism and the CCF's increasingly centrist outlook meant that its policies seemed indistinguishable from those of the Federal Liberal Party. This led to a period of decline for the CCF, later the NDP, during the late-1950s and early-1960s. See Dan Azoulay, Keeping the Dream Alive: The Survival of the Ontario CCF-NDP, 1950-1963 (Montreal and Kingston: McGillQueen's University Press, 1997); Young, The Anatomy of a Party.

79 Co-operative Commonwealth Federation, Women in Peace and War: Protect Your Home (CCF, n.d.), 1-3. The pamphlet was likely written during late-1945 or 1946. 80 CCF News, 6 June 1946.

81 Ibid. 
82 CCF News, 27 November 1947.

83 Ibid.

84 CCF News, 8 April 1948.

85 Ibid.

86 Carol Lee Bacchi, Liberation Deferred? The Ideas of the English-Canadian Suffragists, 1877-1918 (Toronto: University of Toronto Press, 1983), 86-103.

87 Sangster, Dreams of Equality, 224.

88 CCF News, 27 August 1958.

89 Information on these events can be found in Young, Anatomy of a Party.

90 Many texts could be cited here. See Sangster, Transforming Labour, 98-107 and passim; Schrecker, Many are the Crimes; Merrily Weisbord, The Strangest Dream: Canadian Communists, the Spy Trials, and the Cold War (Toronto: Lester \& Orpen Dennys, 1983). On the suicide of diplomat Herbert Norman, who was affiliated with the CP in Britain during the 1930s, see Whitaker and Marcuse, Cold War Canada, ix, 408-409, 420-425.

91 Brown, "The "Savagely Fathered and Un-Mothered World,' " 539

92 Campbell, Rose Henderson: A Woman for the People.

93 Castledine, Cold War Progressives, conclusion.

94 Guard, "Women Worth Watching"; Sangster, Dreams of Equality, 224, 238n. Sangster states, on pp. 224, that a "rupture in historical memory divided women of the Old Left from younger women of the New Left of the 1960s." In her more recent work, notably Transforming Labour, Sangster suggests that there were connections between some women labour activists of the 1950s and second-wave feminism during the $1960 \mathrm{~s}$.

95 Sangster states in Transforming Labour, 105, that Canadian labour women's efforts to promote an equality agenda during the 1940s and 1950s were weaker than for the AFL-CIO in the U.S. To be fair, Sangster is talking about women in the labour movement, and not in left-wing parties like the CP or CCF. My sense is that women's activism in the CP and CCF played a significant role in shaping second-wave feminist activity in Canada and that this, in turn, led to increased equality for women.

96 See Kealey, Enlisting Women for the Cause; Sangster, Dreams of Equality for information on these women.

${ }^{97}$ Lizabeth Cohen, A Consumers' Republic: The Politics of Mass Consumption in Postwar America (New York: Vintage Books, 2003), 8-9 and passim.

98 Dorothy Sue Cobble, The Other Women's Movement: Workplace Justice and Social Rights in Modern America (Princeton: Princeton University Press, 2004); Dennis A. Deslippe, Rights, Not Roses: Unions and the Rise of Working-Class Feminism, 1945-80 (Urbana: University of Illinois Press, 2000); Meg Luxton, "Feminism as a Class Act: Working-Class Feminism and the Women's Movement in Canada," 
Labour/Le Travail 48 (Fall 2001): 63-88. Tarah Brookfield has argued that secondwave feminist groups like the Voice of Women [VOW] borrowed much of their rhetoric from earlier women's groups, who used maternalist ideology and discourse. See Brookfield, Cold War Comforts, 166-188 and passim. Daniel Horowitz and Kate Weigand have similarly argued that American CP women's activism set the stage for second-wave feminism in the U.S. See Daniel Horowitz, Betty

Friedan and the Making of the Feminine Mystique: The American Left, the Cold War, and Modern Feminism (Amherst. MA: University of Massachusetts Press, 1998);

Weigand, Red Feminism, chapter seven. A close discussion of the rise of secondwave feminism is beyond the scope of this paper. 


\section{CANADIAN COMMITTEE ON LABOUR HISTORY}

\section{LABOUR/LE TRAVAIL Journal of Canadian Labour Studies}

Labour/Le Travail began publishing in 1976, and has carried many important articles in the field of working-class history, industrial sociology, labour economics, and labour relations. While most articles have a historical perspective on Canadian workers, the journal is interdisciplinary in scope.

The journal also features documents, conference reports, an annual bibliography of materials in Canadian labour studies, review essays, and reviews. While the main focus of the journal's articles is Canada, the review essays and reviews consider international work of interest to Canadian labour studies.

Many of Labour/Le Travail's articles are illustrated and each issue is book length, averaging $350+$ pages. For a complete listing of volumes and articles, and to order online, visit the journal's website at www.cclh.ca

$\begin{array}{lll} & \text { Canada } & \text { International } \\ \text { Individual/individus: } & 1 \text { Year } \$ 25.00 & 1 \text { Year } \$ 35.00 \\ & 2 \text { Years } \$ 45.00 & 2 \text { Years } \$ 60.00 \\ & 3 \text { Years } \$ 60.00 & 3 \text { Years } \$ 80.00 \\ \text { Institutional/institutionnel: } & 1 \text { Year } \$ 35.00 & 1 \text { Year } \$ 55.00 \\ & 2 \text { Years } \$ 60.00 & 2 \text { Years } \$ 95.00 \\ \text { Student/étudiant(e)s: } & 1 \text { Year } \$ 15.00 & 1 \text { Year } \$ 30.00 \\ & 4 \text { Years } \$ 50.00 & 4 \text { Years } \$ 95.00\end{array}$

* Includes unemployed and retired./Cette categorie inclut les chomeurs ainsi que les retraites. All prices in Canadian dollars, make cheques payable to Athabasca University.

\section{BOOKS: Recent Publications of the CCLH}

The Struggle against Wage Controls: The Saint John Story, 1975-1976

jeorge Vair

SBN 1-894000-07-2, paperback, $\$ 19.95$

Fighting for Dignity:

The Ginger Goodwin Story

zoger Stonebanks

SBN:1-894000-06-4 paperback $\$ 26.95$

A Very Red Life:

The Story of Bill Walsh

sy Goniak

SBN:1-894000-05-6 paperback $\$ 24.95$

A Square Deal for All and No Railroading: Historical Essays on abour in Brandon

:rrol Black and Tom Mitchell, eds.

SBN:1-894000-03-X paperback $\$ 24.95$
Labouring the Canadian Millennium: Writings on Work and Workers, History and Historiography

Bryan D. Palmer, ed.

ISBN:1-894000-04-8 paperback $\$ 20.00$

NEW RELEASE:

Confrontation, Struggle and

Transformation: Organized Labour in the St. Catharines area

Carmela Patrias and Larry Savage

ISBN: 978-1-894000-08-6, paperback, \$14.99

For all our titles, and to order online, visit our website at www.cclh.ca

Send orders with payment to:

Athabasca University

c/o AU Press - CCLH

Peace Hills Trust Tower

1200, 10011-109 Street

Edmonton, AB T5J 358 Canada

Telephone: (780) 497-3412

E-mail:cclh@athabascau.ca

Facsimile: (780) 421-3298 